\title{
Effectiveness of maggot debridement therapy in treating chronic wounds - review of current literature
}

\section{Skuteczność larwaterapii w leczeniu ran przewlektych - przegląd aktualnej literatury}

\author{
Monika Gieroń ${ }^{1}$, Małgorzata Słowik-Rylska', Beata Kręcisz',2 \\ ${ }^{1}$ Dermatology Department, Wojewódzki Szpital Zespolony, Kielce, Poland \\ Head of the Department: Prof. Beata Kręcisz MD, PhD \\ 2Department of Dermatology and Cosmetology, Institute of Medical Sciences, Jan Kochanowski University, Kielce, Poland \\ Head of the Department: Prof. JKU Beata Kręcisz
}

Key words: maggot debridement therapy, chronic wounds, larvae.

Słowa kluczowe: larwaterapia, rany przewlekłe, larwy.

\begin{abstract}
Larval therapy in recent years has gained more interest as a method of treating chronic wounds. It could be an alternative to conventional therapies due to the increasing multidrug resistance of bacteria and observed allergic reactions to antibiotics and disinfectants. The aim of the study was to evaluate the effectiveness and safety of the treatment on the basis of a review of medical databases. Results of the studies have demonstrated greater maggot debridement therapy (MDT) effectiveness in the debridement and stimulation of granulation process over conventional methods. In addition, using this method can shorten the healing time, reduce the consumption of antibiotics, and reduce the cost of treatment. The results of analysed studies are promising; however, it would be advisable to perform randomised, blinded studies with longer follow-up time, in which a larger group of patients would participate.
\end{abstract}

\section{Streszczenie}

Larwaterapia w ostatnich latach zyskuje coraz większe zainteresowanie jako metoda leczenia ran przewlekłych. Stanowi alternatywę dla konwencjonalnych metod terapii ze względu na rosnącą wielolekooporność bakterii i obserwowane reakcje alergiczne na antybiotyki i środki odkażające. Celem pracy była ocena skuteczności i bezpieczeństwa larwaterapii na podstawie przeglądu medycznych baz danych. Wyniki badań wskazują na większą skuteczność larwaterapii w oczyszczaniu ran z martwej tkanki oraz pobudzaniu procesu ziarninowania w stosunku do metod konwencjonalnych. Zastosowanie larwaterapii umożliwia skrócenie czasu leczenia, ograniczenie zużycia antybiotyków i zmniejszenie kosztów leczenia. Wyniki analizowanych badań są obiecujące, natomiast wskazane byłoby zaplanowanie badań z randomizacją przeprowadzonych metodą podwójnie ślepiej próby, z dłuższym czasem obserwacji, w których uczestniczyłaby większa liczba pacjentów.

\section{Introduction}

Nowadays chronic wounds are becoming a growing medical, social, and economic problem. As a result of prolongation of life expectancy, the epidemic of obesity, and loss of physical activity, patients suffer from multiple morbidities. Diabetes mellitus type 2, heart failure, atherosclerosis, and chronic venous disease all impair proper blood supply to tissues and predispose to the formation of chronic ulcers. Despite treatment implementation, hard-to-heal wounds are the reason for deterioration of quality of life, developing depression, worsening of functioning in society, disability, and a higher mortality rate [1-3]. Therefore, there is an ongoing search for more effective therapeutic methods that would shorten treatment time, reduce antibiotic usage, and improve patients' prognosis. In recent years medical associations have been paying more attention to the use of biological dressings containing larvae of green bottle fly Lucilla sericata.

\section{Aim of the research}

The aim of this study was the evaluation of the safety and efficacy of maggot debridement therapy (MDT) in patients with hard-to-heal wounds, conducted on the basis of a review of medical databases.

\section{Material and methods}

Medical databases: PubMed and the Cochrane library were searched for the following phrases: maggot therapy, biosurgery, larval therapy, MDT. No restrictions on publication date and larval species were 
made. Only the studies with control groups were included in the analysis, which was then subdivided according to the methodology used (randomised and non-randomised clinical trials, meta-analyses).

\section{Results}

Using the aforementioned criteria for the analysis, a total of 16 studies were included: 5 randomised clinical trials, 8 non-randomised clinical trials ( 2 prospective and 6 retrospective), and 3 meta-analyses

\section{Randomised comparative clinical trials (RCTs)}

In 2000 Markevich et al. [4] published a clinical study with the participation of 140 patients with diabetic foot ulcer. Seventy patients received larval therapy (MDT), and 70 patients received a hydrogel dressing. The follow-up was 10 days. No statistically significant difference was found in the proportion of patients with completely healed ulcers: $7 \%$ in the MDT group vs. 3\% in the control group. However, statistically significant reduction of wound area $>50 \%$ (51\% MDT vs. $27 \%$ hydrogel) was demonstrated.

In the same year, a study by Wayman et al. appeared [5], involving 12 patients with venous leg ulcers: 6 patients received dressings with free larvae and 6 patients received conventional therapy (Intrasite gel). There was no statistically significant difference in the age, sex, size of the ulcer, or percentage of necrotic tissue at the time of inclusion. Patients with arterial hypertension or previous ineffective therapy were excluded. Wounds were reviewed every $72 \mathrm{~h}$, and the observation time was 1 month. The study assessed the degree of debridement and the time to complete healing ( $<5 \%$ necrosis), the number of necessary check-ups, and the cost to achieve complete debridement of the wound. The study demonstrated greater efficacy and lower costs in MDT compared to patients treated with hydrogel. The wounds in which the larvae were used were completely debrided after one application. However, in the control group only two ulcers were debrided within 1 month. The MDT required three follow-up visits compared to 19 visits in the hydrogel group. The total cost of larvae therapy was 78.64 pounds, while conventional therapy was 136.23 pounds $(p<0.05)$.

The next, randomised, multicentre clinical trial [6] was conducted in the United Kingdom (UK) between 2004 and 2007 by Dumville et al. It involved 267 patients with venous or arteriovenous leg ulcers with at least 25\% necrosis and with ankle-brachial pressure index (ABPI) 0.6 or more. As the primary point of the final assessment was time to complete wound healing, the secondary endpoints were: time to debridement, health related quality of life (including ulcer-related pain), costs of treatment, bacterial load, presence of methicillin-resistant Staphylococcus aureus (MRSA), and adverse events. Observation time ranged from
6 to 12 months. The patients were assigned to three groups: 86 for the group with usage of larvae in bags, 94 to the group with the usage of free larvae, and 87 to the group with usage of hydrogel dressing (Purilon). Dressings with larvae were applied for 3-4 days. In the patients with hydrogel dressing, additional compression therapy was used, depending on ABPI and patients' tolerance. Finally, 139 subjects ( 49 with loose larvae, 46 with bagged larvae, and 44 with hydrogel dressings) completed the study. Among the causes of discontinuation of the study there were: widening of ulcer surface, death for another reason, admission to the hospital for another reason, and the patient's own request. The results showed that there was no difference in time to healing between patients in the MDT group and the conventional therapy group ( $p=0.62,236$ vs. 245 days). Also there was no difference between the group treated with free larvae and those using larvae in pouches $(p=0.66)$. On the other hand, there was statistical significance of the time required for debris removal (14 days for loose larvae, 28 days for bagged larvae, and 72 days for hydrogel dressings, $p<0.001$ ). The time to debridement of wounds in both groups with larval dressing was not statistically significant. In all groups studied, the number of bacteria/ $\mathrm{ml}$ in the ulcers decreased, but there were no statistically significant differences between the groups. There was also no significant difference in reducing the amount of MRSA. Additionally, the number of adverse events and health-related quality of life did not differ between the patients receiving conventional therapy compared to the larval therapy patients. However, significantly higher pain intensity was observed in the patients receiving larval therapy.

Opletalová et al. [7] conducted a randomised, multicentre, single-blind clinical trial (compared with the previous study, patients did not know whether they were receiving MDT or conventional therapy). Between 1993 and 2008, 119 patients were recruited for the study. The following criteria for inclusion were taken into consideration: ulcer area less than $40 \mathrm{~cm}^{2}$, less than $2 \mathrm{~cm}$ of ulcer depth, and ABPI above 0.8 . Patients were evaluated for 15 days of hospitalisation and for 30 days of treatment after leaving the hospital. Out of 119 patients, 105 patients were eventually qualified (51 received MDT, 54 conventional therapy). Larvae in pouches were applied to the wound twice a week for the duration of hospital stay. In the control group wounds were surgically debrided three times a week with scalpel with topical anaesthesia, then the hydrogel dressing was used for dry wounds and alginate or fibre-based dressing for oozing wounds. Due to the blindness of patients, no compression was applied. Selected endpoints (percentage of necrosis tissue, wound humidity, wound healing, pain, comfort of the dressing, MRSA and Pseudomonas aeruginosa presence, time spent on wound care, adverse events) were assessed on the $1^{\text {st }}, 8^{\text {th }}, 15^{\text {th }}$, and $30^{\text {th }}$ day 
of therapy. The study did not show statistical significance in the reduction of necrosis surface on day 1 , 15 , or 30 , but on day 8 of treatment, the difference in necrosis area between the study groups was significant $54.5 \%$ MDT vs. $66.5 \%$ conventional therapy, $p=0.04)$. The healing rate was significantly higher for larval therapy on the $15^{\text {th }}$ day $(p=0.02)$, but on days 8 and 30 there was no difference. The duration of MDT ulcer treatment was $10.1 \mathrm{~min}$ on average, and 40.1 minutes in the control group $(p<0.001)$. The assessment of the remaining endpoints did not show any statistically significant differences.

Another UK study was a randomised, single-blind, multicentre clinical trial published by Mudge et al. [8] in 2014. The study involved 88 patients with venous or mixed arteriovenous ulcers with ABPI above 0.5, and at least $25 \%$ of the necrosis area. Sixty-four patients completed the 21-day study. The patients were divided into two groups: 46 patients received larvae dressing (BioFoam), and 42 patients received hydrogel dressing (Purilon), protected by Interpose dressing. In these patients, compression was applied simultaneously. The main point of the final assessment was the time to debridement. Blinded assessors evaluated whether or not the wound was debrided. The amount of dressing changes, the clinical condition of the wound bed and surrounding skin, and the level of pain were also taken into account. The relationship between size, duration, and aetiology of ulcers was also analysed. The wounds were assessed every 3-4 days up to a total of 21 days or less if complete debridement occurred. Twenty-four subjects did not complete the study (14 MDT patients and 10 control group patients) due to increase in wound secretion/necrosis, aggravation of pain, or at the patient's own request.

In addition, patients were evaluated 7-14 days after the last study visit for recurrence of necrosis. A statistically significant difference was found in favour of larval therapy in removing dead tissue from wounds. Thirty-one ulcers in the MDT arm were fully debrided within 21 days, compared to 11 in the conventional therapy arm. Taking into account the entire population of patients enrolled (88 subjects), this was $67.4 \%$ in the MDT group and $26.2 \%$ in the hydrogel group, respectively. However, considering that some patients did not complete the study, the percentage of fully debrided wounds increased to $96.9 \%$ in MDT and $34.4 \%$ in the hydrogel group. It has also been investigated whether the size, aetiology, or duration of ulceration has an effect on the progress of wound debridement, showing only a statistically significant correlation with the size of the wound area. Large ulcers were not fully debrided within 21 days $(p=0.003)$. Patients treated with larvae experienced greater pain compared to patients in the control group $(p<0.001)$. In contrast, there were no differences in condition of wound bed and the surrounding skin between the treatments used. Patients treated with MDT required significantly fewer visits: an average of 2.88 visits versus the hydrogel group in which 5.4 visits were required $(p<0.001)$. Fifteen patients treated with MDT required only one visit, while 19 patients treated with conventional therapy did not receive full therapeutic effect during the study. There was a significantly higher percentage of recurrence of necrosis in completely debrided wounds in the MDT group (71\% vs. $27 \%$ in the control group, $p=0.011$ ).

\section{Non-randomised clinical trials}

\section{Prospective}

In 1995, Sherman et al. [9] published a prospective, clinical study evaluating the efficacy of larval therapy in patients with pressure ulcers after spinal cord injuries. The study involved 8 patients previously treated for 3-4 weeks with conventional therapy - saline dressing, sodium hypochlorite, povidone iodine dressings, and antimicrobial ointments, combined with surgical debridement (control group). Patients were provided with dressings of free larvae of Lucilla sericata, which were applied for $48-72 \mathrm{~h}$, once or twice a week. Between cycles of larval dressings sodium hypochlorite, saline, or wet-dry dressings were used, changed every $8 \mathrm{~h}$. During the study, the wound was assessed once a week for surface area, tissue quality, and healing index. During conventional therapy, none of the wounds with more than $20 \%$ of the necrotic area was debrided more than $50 \%$, but after larvae application the wounds were completely debrided after 1-2 weeks of treatment. Before the application of maggots, the area of wounds increased on average by $21.8 \%$, and after the treatment they decreased by $22 \%(p<0.001)$. No adverse events were reported; the treatment was well tolerated.

The study published by Paul et al. in 2009 [10] concerned another larval species: Lucilla cuprina. Between 2005 and 2007, 59 patients with diabetic foot ulcers were assigned to two groups: 29 patients were enrolled in the larval therapy group and 30 patients in the control group, and they received surgical debridement and physiological saline dressings, respectively. Patients were excluded when the ABPI was less than 0.75 , with exposed bones or tendons, gangrene, necrotising fasciitis, and abscesses. Free larvae were applied for $48 \mathrm{~h}$, and therapy was repeated when necessary. The main endpoint of the study was the appearance of healing, considered as self-healing of wound, when the wound was suitable for split skin grafting (SSG) or flap coverage, or when the wound was suitable for SSG or flap coverage, previously debrided, or surgically removed from necrotic bone and ligament.

In the MDT group, 14 wounds were healed, 11 were not healed, and four patients did not complete the study. In the control group, 18 wounds were cured, 11 were not cured, and 1 patient did not complete the 
study. There were no significant differences between the two groups $(p>0.05)$.

\section{Retrospective}

In 2002 Sherman et al. [11] published a retrospective cohort study evaluating patients with pressure ulcers in the years 1990-1995. The criteria for inclusion were fulfilled by 67 patients with 92 wounds, 49 of which were treated by conventional methods and 43 by Lucilla sericata. Local antimicrobial agents, hydrogel, hydrocolloid dressings, alginates, wet to dry dressings, chemical debriding agents, growth factors, or combinations of these methods were used in conventional treatment. Some of the wounds were also surgically treated. Larvae were applied twice a week for $48 \mathrm{~h}$. Once a week the parameters such as change in wound area, dead tissue presence, amount of granulation tissue, healing and/or debridement rate were measured. The median duration of therapy was 5.5 weeks in the conventionally treated group and 4.8 weeks in the MDT group. At that time the larvae completely debride $80 \%$ of wounds, compared to $48 \%$ in the control group $(p=0.021)$. Within 3 weeks, larvaltreated wounds contained one-third the necrotic tissue $(p=0.05)$ and twice the granulation tissue $(p<0.001)$. MDT-treated wounds were deprived of half-dead tissue after 1.4 weeks. Twice as many wounds treated with larval therapy were granulated in over $50 \%$ of the area during treatment ( $49 \%$ vs. $18 \%, p=0.002$ ). The percentage of granular tissue area increased on average by $13 \%$ per week in the MDT group and by 3.3\% in the control group. Thirty-nine percent of wounds underwent larval therapy and $21 \%$ of conventionally treated wounds were completely healed in less than 12 weeks, which was not statistically significant. The mean time to complete healing was 12 weeks for MDT and 13.4 weeks for conventional therapy.

A year later Sherman et al. [12] presented a study aimed at assessing the treatment of free Lucilla sericata larvae in patients with diabetic foot ulcers nonresponsive to conventional therapy. Twenty wounds were analysed in 18 patients: 6 wounds were treated with MDT, 6 were treated with conventional therapy, and 8 first with conventional therapy and then with larvae. Wounds were assessed once a week for at least 8 weeks. Larvae were applied 1-2 times per week for $48 \mathrm{~h}$. Conventional methods of therapy were hydrogels, hydrocolloid dressings, local antibacterial agents, wet to dry dressings, and variations of these or surgical debridement. For the first 14 days of treatment in the larval group, the reduction of necrosis was on average $4.1 \mathrm{~cm}^{2}$, but in the control group no effect was recorded. In wounds treated with larval therapy a 50\% reduction of necrosis was reached by day 9; conventionally-treated wounds did not achieve this even by 29 days ( $p<0.001)$. After 5 weeks, conventional treated wounds were debrided less than $67 \%$, as opposed to totally debrided wounds in larval group $(p=0.001)$. Weekly change in surface area $\left(\mathrm{cm}^{2}\right)$ was +1.15 for the conventional therapy group $(0.24-2.1)$ and -0.78 for MDT $(-1.6-0.1)$. The healing rate at 8 weeks was -0.02 ( -0.08 to 0.04 ) for conventional therapy and 0.07 for maggot therapy (0.04 to 0.11$)$. There was also a faster formation of granulation tissue with larval therapy after 4 weeks (56\% of surface versus $15 \%$ of surface of conventionally treated wounds, $p=0.016)$. The difference in wound area in ulcers treated first with conventional therapy and then with larval therapy was also statistically significant: in the MDT group it decreased by $0.9 \mathrm{~cm}^{2} /$ week while in the conventionally treated group it increased by $1.0 \mathrm{~cm}^{2} /$ week $(p=0.018)$.

Another study conducted by Sherman and Shimoda in 2004 [13] evaluated the effectiveness of preoperative larval therapy in the prevention of postoperative wound infection. Twenty-nine wounds in 25 patients closed intraoperatively were analysed: in 10 wounds MDT was used prior to surgery and in 19 it was not. The median time interval between completion of the MDT and the operation was 5.7 days. The number of applied larval therapy cycles was 1 to 29 , with an average of 9.7. Wounds were qualified for procedures such as amputation, flap coverage, primary closure, and split-thickness skin graft. There was no post-operative infection in the MDT group, but in 6 (32\%) wounds that had not been treated with maggots, postoperative infection with subsequent dehiscence $(p<0.05)$ occurred. Excluding from the analysis those patients who subsequently underwent amputation, there was also a statistically significant difference between the two groups $(p<0.005)$. There are no data of follow-up length.

In 2005, Armstrong et al. [14] published a study on patients with neuroischaemic diabetic foot ulcers and peripheral vascular disease. The study included 60 patients with diabetes, a single foot wound, no mobility without assistive devices, and peripheral vascular disease. Follow-up lasted 6 months. Of the 60 patients, 27 (45\%) had complete healing within 6 months, with no significant difference between the groups (57\% in the larval group vs. $33 \%$ in the control group, $p=0.07)$. The time to heal was significantly shorter in the MDT group $(18.5 \pm 4.8$ weeks vs. $22.4 \pm 4.4$ weeks, $p=0.04)$. Twenty-two percent of patients underwent high amputation of the limb (33\% for conventional therapy group vs. $10 \%$ for the MDT group). Patients undergoing larval therapy had more antibiotic-free days (126.8 \pm 30.3 days vs. $81.9 \pm 42.1$ days, $p=0.0001)$.

In 2010, Wang et al. [15] published a study in which 25 patients with diabetic foot ulcers and 18 patients with pressure ulcers after spinal cord injuries participated. During the study, all ulcers were fully healed, and during the follow-up lasting 2 to 6 months the ulcers did not return. In the clinical group, dressing with 5-10 free larvae/ $\mathrm{cm}^{2}$ was used. Saline dressings were used in the control group and, if necessary, surgical debridement. In both groups systemic 
antibiotics were not used. Time to granulation, time to negative culture and time to heal were evaluated. Both patients with diabetic foot and patients with pressure ulcers achieved greater efficacy in the MDT group in all evaluated outcomes $(p<0.05)$. The time to reach negative culture in patients with diabetic foot syndrome and pressure ulcers after core injury was significantly shorter with MDT (12.0 \pm 2.5 days vs. $16.1 \pm 3.8$ days, $p=0.004 ; 10.4 \pm 1.8$ days vs. $13.1 \pm 2.2$ days, $p=0.022$ ). Time to start granulation respectively (3.1 \pm 1.2 days vs. $6.3 \pm 1.2$ days, $p=0.000 ; 2.5 \pm 1.0$ days vs. $4.8 \pm 1.0$ days, $p<0.001)$, healing time $(26.4$ \pm 12.6 days vs. $39.6 \pm 13.4$ days, $p=0.042,18.7 \pm 10.4$ days vs. $30.6 \pm 12.2$ days, $p=0.039$ ).

Three years later Wilasrusmee et al. [16] published a study with 111 patients with diabetic foot syndrome. The qualification criteria were: presence of a single foot wound, ability to move independently without assistive devices, period of 6 months of observation, and a wound without: gangrene, necrotising fasciitis, abscess, or osteomyelitis. Fifty-nine patients were treated with bagged larvae (median: 8.25 applications per patient), and 52 patients were treated with saline or hydrogel dressings and, if necessary, surgical debridement (median: 8.79 times/patient). The wounds were evaluated once per week. The wound was considered as healed if 95\% epithelialisation occurred, with the absence of scabs, when the wound was suitable for split skin grafting, flap coverage or, self-healing. The mean age of patients and glycated haemoglobin $\left(\mathrm{HbA}_{1 c}\right)$ level was similar in both groups. However, in the MDT group, more patients had smaller wounds and shorter duration of ulcer and also had a lower proportion of patients with abnormal ABPI than in the control group. The ulcers of 64 patients were healed during a median of 14 weeks. Median healing time was significantly lower in the MDT group ( 9 weeks vs. 28 weeks). In addition, ABPI, duration and size of the wound affected the healing time. Median healing time was lower in patients with wounds that lasted $<20$ days ( 8 weeks vs. 15 weeks, $p<0.001$ ), in patients with wound area $<(9$ weeks vs. 15 weeks, $p<0.001$ ), and correct ABPI (10 weeks vs. 15 weeks, $p=0.01)$. Statistical analysis showed that after adjustment for $\mathrm{ABPI}, \mathrm{HbA}_{1 \mathrm{c}}$, size, and duration of ulceration, the overall healing chance was about 7.7 times higher in the MDT group compared to the control group. The healing rate was $12 / 100$ patient-weeks in the MDT group compared to $2 / 100$ patient-weeks in the control group. The cost of treatment was also analysed, including nursing care, hospital admission, and dressings applied. The median cost of treatment was lower in the MDT group (\$ 292.82 vs. $\$ 490, p<0.001$ ).

\section{Meta-analyses}

In 2013, Tian et al. [17] performed a meta-analysis of publications on MDT efficacy in the treatment of diabetic foot ulcers. Seven databases up to December 31, 2012 were searched. The RCTs, case-control studies, and controlled clinical trials were considered. The required criteria were met by four publications: Markevich et al. (2000), Sherman (2003), Paul et al. (2009), and Armstrong et al. (2005) with a total of 356 participants, including 180 patients of MDTs and 176 of conventional therapies. The following results were analysed: healing rate, time to healing, incidence of infection, amputation rate, and antibiotic usage. The analysis of the healing rate showed no difference between the groups (relative risk $(\mathrm{RR})=1.33$, 95\% confidence interval (CI): 0.94, 1.88, $p=0.11$ ). However, in one study, healing was defined in a different way, which could have resulted in an error in the results. Excluding the above study, a statistically significant difference was found in favour of MDT compared to controls ( $\mathrm{RR}=1.80,95 \% \mathrm{CI}: 1.07,3.02, p=0.03$ ). Two trials evaluated the amputation rate. A statistically significant difference was found between the study groups in favour of MDT $(\mathrm{RR}=0.41,95 \% \mathrm{CI}$ : $0.20,0.85, p=0.002)$. There were no differences in incidence of infection $(\mathrm{RR}=0.82,95 \% \mathrm{CI}: 0.65,1.04$, $p=0.1$ ). Two studies, which evaluated time to healing, showed a significant difference between MDT and control groups $(\mathrm{RR}=-3.70,95 \% \mathrm{CI}:-5.76 ;-1.64$, $p=0.0004)$. The two studies evaluated the use of antibiotics. In the first study $96 \%$ of the MDT group and $97 \%$ of the conventional group received antibiotic therapy $(p<0.05)$. In the second study, antibiotic-free days were evaluated, with data in favour of MDT (126.8 \pm 30.3 days vs. $81.9 \pm 42.1$ days). The authors draw attention to the numerous limitations of meta-analysis: a small number of randomised clinical trials, the use of only English-language literature, the differences in methodology, and the small number of participants.

In the same year, Wilasrusmee et al. [16] published a meta-analysis of six studies (Paul et al.; Armstrong et al.; Sherman et al., 2002; Sherman et al., 2003; Wilasrusmee et al., Dumville et al.) on larval therapy in the treatment of chronic wounds. The wound healing rate and/or healing time and cost-effectiveness were analysed. From the studies qualified for meta-analysis, two studies were prospective, three were retrospective, and one was a multicentre randomised clinical trial. Four studies were related to diabetic, one to venous, and one to pressure ulcers. The total number of participants was 612. The analysis of wound healing rate in five trials ( 171 vs. 174 patients) showed that the chance of ulcer healing was $77 \%$ greater in larval patients $(\mathrm{RR}=1.77 ; 95 \% \mathrm{CI}$ : 1.01, 3.11). Pooled RR after the addition of RCT for analysis was 1.53 (95\% CI: 1.23, 1.9). In four studies, healing time was compared (146 vs. 145 patients). The analysis showed that the healing time was 15.99 days shorter in the MDT group, although the difference was not statistically significant. After the RCT was added for analysis 
$(n=585)$, the difference in healing times was 14.56 days. The median cost of treatment was lower in the MDT group (\$ 292.82 vs. $\$ 490, p<0.001)$.

The meta-analysis containing the greatest number of studies was Sun et al.'s work in 2014 [18]. It pertained to 12 studies selected from available literature (Markevich et al., Wayman et al., Sherman et al., 2002; Sherman et al., 2003; Armstrong et al.; Dumville et al.; Paul et al.; Soares et al.; Wang et al.; Meng and Zhang; Wilasrusmee et al.; Mudge et al.), with a total of 959 patients (530 in MDT, 429 in control). The healing rate, time to healing, incidence of infection, amputation rate, antibiotic-free days, and antibiotic usage were analysed. Eight studies compared healing rates. Pooled RR for the MDT group was 1.8 (95\% CI: 1.24-2.6). Subgroup analyses were also performed. For patients with diabetic foot ulcers (DFU) pooled RR was 1.79 (95\% CI: 0.95-3.38), for pressure and venous ulcers it was 1.7 (95\% CI: 1.28-2.27).

Only one study evaluated infection rate and antibiotic-free days. It showed no statistically significant difference in the rate of infection between the groups (80\% MDT vs. $60 \%$ in the control group, $p>0.05)$, although there was a statistically significant difference in antibiotic-free days (126.8 \pm 30.3 MDT vs. $81.9 \pm 42.1$ control, $p<0.001)$. The results of two studies did not show a statistically significant difference in antibiotic consumption (69.2\% MDT vs. 69.8\% control). Pooled RR was 1.03 (95\% CI: 0.87-1.22) for MDT. Patients in the control group had almost twice the risk of amputation ( $\mathrm{RR}=0.43,95 \% \mathrm{CI}$ : 0.21-0.88). Four studies showed a shorter healing time for larval therapy. Pooled standardised mean difference (SMD) was -0.95 (95\% CI: $-1.24,-0.65, p=0.502)$. In addition, a study analysis divided into studies of diabetic (three studies) and other aetiology ulcers (two studies) demonstrated MDT healing superiority (DFU SMD = $-0.79,95 \%$ CI: $-1.18,-041$; for other wounds SMD = -1.16 ; $95 \%$ CI: $-1.63,-0.63)$.

Two studies (Wayman et al.; Soares et al.) compared the costs of applied therapies. SMD - 0.48, 95\% CI: -1.76 ; 0.80)

\section{Discussion}

The first references to larval therapy come from 1557. It was used by A. Pare on infected battle wounds of soldiers of the French Army during the battle of St. Quentin. The next reports of successful wound debridement by larvae of flies date back to the Napoleonic wars and the US Civil War. During the First World War, William Baer, an American orthopaedic surgeon, observed that faster healing occurs in wounds infected with larvae. In 1929 he successfully applied Lucilla sericata larvae for the treatment of osteomyelitis in children. For many years this method was widely used by many surgeons. It was abandoned after the introduction and spread of antibiotics in the 1940s [19-23]. It is currently returning to grace due to the increasing antibiotic resistance of bacteria.

Larvae debride the wound through several synergistic mechanisms: mechanical wound debridement, extracorporeal digestion of dead tissues, and bactericidal action. They also secrete growth factors that contribute to the formation of granulation tissue. Larvae are necrophagous, nourishing necrotic tissues only, saving live tissue. They secrete a number of enzymes and substances such as carboxypeptidase, collagenase, lucifensin, chymotrypsin, nuclease, and MAMP, which besides necrotic tissue digestion, also digest bonds of bacterial biofilm and bacterial DNA, as well as inhibit inflammation [24-26].

Currently this method differs from that of the sixteenth century. Larvae are kept under sterile conditions and stored at a suitable low temperature, to provide ideal conditions for growth and survival [27-29].

Lucilla sericata is the most widely used species. The larvae are free or enclosed in special pouches. The dressing is applied to the wound, usually for $48-72 \mathrm{~h}$, and protected with moist gauze.

Distribution is wide. In addition to wounds such as venous leg ulcers, pressure ulcers, arterial ulcers, and diabetic foot syndrome, they are also increasingly used in burns, traumatic wounds, postoperative wounds, osteomyelitis, and necrotising fasciitis.

A review of literature indicates the efficacy of larval therapy in the treatment of chronic wounds. Most studies have shown an advantage of MDT over conventional methods in the debridement, stimulation of granulation process, and shortening of healing time, with a relatively small amount of side effects, the most commonly reported of which is pain. The use of larvae can also reduce the overall cost of treating hardto-heal wounds, shortening the time spent in hospital wards, and reducing the consumption of antibiotics. This is an alternative for patients who, for medical reasons, are contraindicated for surgical debridement, which often involves the need for anaesthesia.

The results of previous studies are promising, while a relatively small number of them, including randomised, prospective, blinded studies, with more participants, with longer follow-ups andclear explicit criteria for inclusion and exclusion, indicate the need for further research.

\section{Conflict of interest}

The authors declare no conflict of interest.

\section{References}

1. Richmond NA, Maderal AD, Vivas AC. Evidence-based management of common chronic lower extremity ulcers. Dermatol Ther 2013; 26: 187-96.

2. Herber OR, Schnepp W, Rieger MA. A systematic review on the impact of leg ulceration on patients' quality of life. Health Qual Life Outcomes 2007; 5: 44. 
3. Evidence-based (S3) guidelines for diagnostics and treatment of venous leg ulcers. J Eur Acad Dermatol Venereol 2016; 30: 1843-75.

4. Markevich YO, McLeod-Roberts J, Mousley M, Melloy E. Maggot therapy for diabetic neuropathic foot wounds. Diabetologia 2000; 43 (Suppl. 1): a15.

5. Wayman J, Nirojogi V, Walker A, Sowinski A, Walker MA. The cost effectiveness of larval therapy in venous ulcers. J Tissue Viability 2000; 10: 91-4.

6. Dumville JC, Worthy G, Bland JM. Cullum N, Dowson C, Iglesias C, Mitchell JL, Nelson EA, Soares MO, Torgerson DJ; VenUS II team. Larval therapy for leg ulcers (VenUS II): randomised controlled trial. BMJ 2009; 338: b773.

7. Opletalová K, Blaizot X, Mourgeon B, Chêne Y, Creveuil C, Combemale P, Laplaud AL, Sohyer-Lebreuilly I, Dompmartin A. Maggot therapy for wound debridement: a randomized multicenter trial. Arch Dermatol 2012; 148: 432-8.

8. Mudge E, Price P, Walkley N, Harding KG. A randomized controlled trial of larval therapy for the debridement of leg ulcers: results of a multicenter, randomized, controlled, open, observer blind, parallel group study. Wound Repair Regen 2014; 22: 43-51.

9. Sherman RA, Wyle F, Vulpe M. Maggot therapy for treating pressure ulcers in spinal cord injury patients. J Spinal Cord Med 1995; 18: 71-4.

10. Paul AG, Ahmad NW, Lee HL, Ariff AM, Saranum M, Naicker AS, Osman Z. Maggot debridement therapy with Lucilia cuprina: a comparison with conventional debridement in diabetic foot ulcers. Int Wound J 2009; 6: 39-46.

11. Sherman RA. Maggot versus conservative debridement therapy for the treatment of pressure ulcers. Wound Repair Regen 2002; 10: 208-14.

12. Sherman RA. Maggot therapy for treating diabetic foot ulcers unresponsive to conventional therapy. Diabetes Care 2003; 26: 446-51.

13. Sherman RA, Shimoda KJ. Presurgical maggot debridement of soft tissue wounds is associated with decreased rates of postoperative infection. Clin Infect Dis 2004; 39: 1067-70.

14. Armstrong DG, Salas P, Short B, Martin BR, Kimbriel HR, Nixon BP, Boulton AJM. Maggot Therapy in "LowerExtremity Hospice" Wound Care. Fewer amputations and more antibiotic-free days. J Am Podiatr Med Assoc 2005; 95: 254-57.

15. Wang SY, Wang JN, Lv DC, Diao YP, Zhang Z. Clinical research on the bio-debridement effect of maggot therapy for treatment of chronically infected lesions. Orthop Surg 2010; 2: 201-6.

16. Wilasrusmee C, Marjareonrungrung M, Eamkong S, Attia J, Poprom N, Jirasisrithum S, Thakkinstian A. Maggot therapy for chronic ulcer: a retrospective cohort and a meta-analysis. Asian J Surg 2014; 37: 138-47.

17. Tian X, Liang XM, Song GM, Zhao Y, Yang XL. Maggot debridement therapy for the treatment of diabetic foot ulcers: a meta-analysis. J Wound Care 2013; 22: 462-9.

18. Sun X, Jiang K, Chen J, Wu L, Lu H, Wang A, Wang J. A systematic review of maggot debridement therapy for chronically infected wounds and ulcers. Int J Infect Dis 2014; 25: 32-7.

19. Sherman RA, Hall MJ, Thomas S. Medicinal maggots: an ancient remedy for some contemporary afflictions. Annu Rev Entomol 2000; 45: 55-81.
20. Whitaker IS, Twine C, Whitaker MJ, Welck M, Brown CS, Shandall A. Larval therapy from antiquity to the present day: mechanisms of action, clinical applications and future potential. Postgrad Med J 2007; 83: 409-13.

21. Church JCT. Larva therapy in modern wound care: a review. primary intention. Australian J Wound Manag 1999; May: 63-8.

22. Baer WS. The classic: the treatment of chronic osteomyelitis with the maggot (larva of the blow fly). Clin Orthop Relat Res 2011; 469: 920-44.

23. Sherman RA, Pechter EA. Maggot therapy: a review of the therapeutic applications of fly larvae in human medicine, especially for treating osteomyelitis. Med Vet Entomol 1988; 2: 225-30

24. Cazander G, Pritchard DI, Nigam Y, Jung W, Nibbering PH. Multiple actions of Lucilia sericata larvae in hard to heal wounds. Bioessays 2013; 35: 1083-92.

25. Nigam Y, Morgan C. Does maggot therapy promote wound healing? The clinical and cellular evidence. J Eur Acad Dermatol Venereol 2016; 30: 776-82.

26. Pritchard DI, Čeřovský V, Nigam Y, Pickles SF, Cazander G, Nibbering PH, Bültemann A, Jung W. TIME management by medicinal larvae. Int Wound J 2016; 13: 475-84.

27. Barne KM. Gennard DE. Rearing bacteria and maggots concurrently: a protocol using Lucilia sericata (Diptera: Calliphoridae) as a model species. Appl Entomol Zool 2013; 48: 247-53.

28. Wolff $\mathrm{H}$, Hansson C. Rearing larvae of Lucilia sericata for chronic ulcer treatment: an improved method. Acta Derm Venereol 2005; 85: 126-31.

29. Beasley WD, Hirst G. Making a meal of MRSA - the role of biosurgery in hospital-acquired infection. J Hosp Infect 2004; 56: 6-9.

\section{Address for correspondence:}

\section{Monika Gieroń}

Dermatology Department

Wojewódzki Szpital Zespolony

ul. Radiowa 7, 25-317 Kielce, Poland

Phone: +48 668130798

E-mail: monika.chlon@gmail.com 